\title{
The Influence of Cognitive Styles as Promoters of Entrepreneurial Orientation and Intrapreneurship as Drivers of Innovation: The Case of Nurses in Health Services in Portugal in Times of COVID-19
}

\author{
Paula Ferraz $^{1}$, Carla Susana Marques ${ }^{2, *}$, , Gina Santos ${ }^{2}\left(\mathbb{D}\right.$, Ariana Moreno Cunha ${ }^{1}\left(\mathbb{D}\right.$ and Sérgio Vaz ${ }^{1(\mathbb{C})}$ \\ 1 Centro Hospitalar de Trás-os-Montes e Alto Douro (CHTMAD), 5000-801 Vila Real, Portugal; \\ pmouraferraz@gmail.com (P.F.); ariana-moreno@hotmail.com (A.M.C.); sergiovazn6@hotmail.com (S.V.) \\ 2 CETRAD Research Center, Department of Economics Sociology and Management, \\ University of Trás-os-Montes e Alto Douro, 5000-801 Vila Real, Portugal; gina.santos@utad.pt \\ * Correspondence: smarques@utad.pt
}

check for updates

Citation: Ferraz, Paula, Carla Susana Marques, Gina Santos, Ariana

Moreno Cunha, and Sérgio Vaz. 2021. The Influence of Cognitive Styles as Promoters of Entrepreneurial Orientation and Intrapreneurship as Drivers of Innovation: The Case of Nurses in Health Services in Portugal in Times of COVID-19. Administrative Sciences 11: 107. https://doi.org/ 10.3390/admsci11040107

Received: 26 August 2021

Accepted: 15 September 2021

Published: 28 September 2021

Publisher's Note: MDPI stays neutral with regard to jurisdictional claims in published maps and institutional affiliations.

Copyright: (c) 2021 by the authors. Licensee MDPI, Basel, Switzerland. This article is an open access article distributed under the terms and conditions of the Creative Commons Attribution (CC BY) license (https:// creativecommons.org/licenses/by/ $4.0 /)$.

\begin{abstract}
The main objective of this study is to assess how cognitive styles promote individual entrepreneurial orientation (IOE) and intrapreneurship and how they drive innovation among nurses in the healthcare services in Portugal. A total of 667 nurses participated, by completing an online questionnaire in the midst of the COVID-19 pandemic, working in different health units in Portugal. PLS-SEM structural equation modelling was used as a data analysis technique. The results show that cognitive styles have a positive influence on nurses' IOE; that cognitive styles have a positive influence on intrapreneurship, which is mediated by the IO; that the IOE impacts nurses' intrapreneurship and innovation, which is mediated by intrapreneurship; and that intrapreneurship impacts nurses' innovation. The originality of this study lies in the absence of studies showing relationships between the dimensions that we propose to analyze during the pandemic of COVID-19.
\end{abstract}

Keywords: cognitive styles; individual entrepreneurial orientation; intrapreneurship; innovation; nurses; COVID-19

\section{Introduction}

Innovation in health is a creative process that requires imagination, courage, optimism (Kooli 2021a), and entrepreneurship; modifies knowledge into tangible products, processes, and procedures; and adds value in various areas of health: better health, higher quality of care, the economy, and the quality of relationships between professional classes (Hagatong 2018). In nursing, innovation is a motivating factor. Professionals can use knowledge and obtained skills to generate and develop creative ways of working based on different technologies and systems (Weng et al. 2013).

Entrepreneurship is a holistic and dynamic process where the elements of a specific project share risks, individual behaviors are modified (even if the individuals did not decide consciously to be entrepreneurs), and where organizational factors are crucial in the development of entrepreneurial behavior and innovation within the organization (Antoncic and Hisrich 2003; Abadli et al. 2020; Kooli 2020). The theme of intrapreneurship (IE) is relevant to the performance of the company or organization and is becoming more relevant both at the academic and professional levels, although it is still poorly explored in terms of empirical evidence (Lages et al. 2017).

It should also be noted that, in times of pandemics, nurses are faced with completely new situations that require a rapid execution, which makes the dimensions under study even more important to the scientific world, to the extent that innovation is a motivating factor, it uses knowledge, and it tends to generate work methods or innovative ideas. It 
is an original study, and it generates value in health and management because they are interconnected. Nurses who have OEI are intrapreneurs and promote innovation.

Thus, the main objective of this study is to assess how cognitive styles (CS) promote IOE and IE and how these promote innovation among nurses in healthcare services in Portugal. We also intend to assess whether rational and intuitive CS influence IOE and IE; analyze the effect of IOE on IE; and how they promote innovation among nurses in the health services in Portugal.

Based on the literature review, we found that, although there are some studies in the areas of entrepreneurial orientation (EO), innovation, and intrapreneurship, this study with nurses in Portugal, namely the relationships and respective dimensions that we intend to analyze, contributes to increasing the knowledge about intrapreneurial behavior, taking into account the AEs and their EO as antecedents of this behavior and innovation as consequences. It should also be noted that the sample was collected in the middle of the COVID-19 pandemic, where nurses who were on the frontline in the fight against and treatment of patients with COVID-19 were still exhausted.

The article is divided into six sections. In the following section, we expose the theoretical foundations of the addressed topics which support the research hypotheses that gives rise to the proposal of the conceptual research model. Next, the methodology used in this research is presented. In the fourth section, we present the main results, namely the characterization of the sample, the validation of the measurement instrument, and the structural equation model based on the proposed conceptual research model. Subsequently, the discussion of the results is presented, and, in the last section, the main conclusions and implications of the study are mentioned, as well as the suggestions for future research.

\section{Literature Review}

\subsection{Cognitive Styles: Rational and Intuitive}

CS influence entrepreneurial success. They are defined as consistent individual differences in perception, behavior, problem solving, decision making, and relationships with others in the creative process (Armstrong et al. 2012; Chen et al. 2015).

Individuals with intuitive or holistic CS are more confident in identifying and recognizing opportunities but are more insecure in their ability to evaluate, plan, and organize resources (Kickul et al. 2009) and exhibit higher levels of entrepreneurial intentions, whereas individuals with rational or analytical CS are more confident in their abilities to evaluate, plan, and mobilize resources but are less confident in research skills and recognizing new opportunities (Kickul et al. 2009).

Dutta and Thornhill (2014) state that the analytical entrepreneur operates with a rational CS, whereas the intuitive (holistic) entrepreneur operates with an intuitive CS. The same authors concluded that high entrepreneurial growth intentions are likely to arise from entrepreneurs who use effectiveness-oriented cognitive logic by intuitive CS. Entrepreneurs who use analytical-style-oriented cognitive logic are likely to have incremental growth intentions.

Entrepreneurs hold cognitive structures that they use to accelerate information processing, decision-making processes, and effectiveness, aiding the success of the organization when faced with complex and dubious situations such as information overload, uncertainty or novelty, strong emotions, time pressure, and fatigue (Baron 2004; Kooli 2019). It is perceived then that entrepreneurial cognition provides a basis for identifying those who have the potential to act as successful entrepreneurs (Allinson et al. 2010).

\subsection{Individual Entrepreneurial Orientation}

At IOE, the person has a personality that takes the risk, is proactive and provides the best entrepreneurial attitude for the company (Awang et al. 2016).

Entrepreneurs possess five individual characteristics that influence organizational management: innovation ability, risk taking, proactivity, autonomy, and competitive ag- 
gressiveness (Lumpkin et al. 2009); with IOE being an influential factor in recognizing opportunities and improving organizational performance (Santos et al. 2020).

Santos et al. (2020) validated a scale with emerging dimensions of IOE, passion, and perseverance, together with innovation ability, proactivity, and risk taking. Entrepreneurs possess these individual characteristics.

Kraus et al. (2019) refer to the relationship of IOE and exploration activities at the individual level, which exposes that employees with a high level of IOE are more likely to work on exploratory activities and that they are the support of the intrapreneurial process, while IOE does not seem to have an influence on exploratory activities. On the other hand, change as a moderator variable reveals a positive effect on the IOE exploration relationship. Therefore, employees with a high level of IOE and change are more likely to discover new opportunities as they engage in exploratory activities. Organizations that intend to develop intrapreneurial activities need to hire people with a high level of IOE.

Considering the above, the following research hypotheses were developed:

Hypothesis 1 (H1). Rational CS influences IOE.

Hypothesis 2 (H2). Intuitive CS influences IOE.

\subsection{Intrapreneurship}

Gawke et al. (2019) define employee IE as a strategic agent behavior to create new ventures for the organization, i.e., the adoption of a risk-taking and strategic renewal behavior, promoting an improvement in the organization's ability to react to internal and external advances (Gawke et al. 2017, 2018). In the same line of thinking, Kooli (2021b) considers medical practitioners as important decision makers especially in challenging situation; thus, they would require upholding fundamental principles of medical ethics such as nonmaleficence, justice, autonomy, and beneficence. It is necessary to take into account the need to change public and health policies so that institutions are prepared for extreme situations.

The intrapreneurial behavior of employees is essential for strategic interest in the performance of an organization (Neessen et al. 2019). Kooli and Abadli (2021) consider that institutions need to encourage interest, motivation, and commitment emerging in professional development. A set of skills, the perception of their own capabilities, personal knowledge, experience, relationship with the organization, motivation, satisfaction, and intention are the determinants of intrapreneurial behavior (Neessen et al. 2019).

The relationship between individual behavior and organizational results evidences the impact of the intrapreneur on the company. The study conducted by Marques et al. (2018) concluded that personal attributes, motivation, and entrepreneurial skills are factors that explain nurses' entrepreneurial intention in their organizations.

Ortiz-Hunt et al. (2019) developed and tested the premise that entrepreneurial orientation in hospitals, evidenced through the development and implementation of IE programs for nurses, is a decisive factor in achieving sustainable healthcare. The obtained results revealed that nurses are the main group of stakeholders in achieving material and positive effects on the sustainability of healthcare delivery and performing intrapreneurial behaviors (Ortiz-Hunt et al. 2019).

The results of Pandey et al. (2020) study highlight the existence of positive relationships between IE, CS, and work engagement. The study of Marques et al. (2021) reveals that cognitive style plays a significant role in intrapreneurship of healthcare professionals. In particular, healthcare professionals with the rational cognitive style are likely to be more of an intrapreneur and innovative as compared to those with an intuitive cognitive style.

Based on the above, the following research hypotheses were developed: 
Hypothesis 3 (H3). Rational CS influences IE.

Hypothesis 4 (H4). Intuitive CS influences IE.

Hypothesis $\mathbf{5}$ (H5). IOE influences IE.

\subsection{Innovation}

Innovation is the tool of entrepreneurs, who exploit change as an opportunity for a distinctive business or service. Innovative individual is the entrepreneur's engine of growth (Abadli et al. 2020). Innovation is a multidimensional phenomenon that incorporates the behaviors and interactions of individuals and various organizational factors. The combination of entrepreneurship and innovation is vital to organizational success (Urban and Wood 2017).

Technological and organizational innovation improves employee performance and fosters the relationship between employee and customer. Organizational innovation allows the employee to be allocated to the area that best dominates and performs (Messabia et al. 2020).

Individuals are the center of innovation as they are active observers in the presence of innovation and agents of change (Afsar et al. 2015; Tabak et al. 2010). In Messabia et al.'s (2020) study, it was found that coaching and various types of physical and virtual training are essential to promoting change and generating personal and organizational development skills.

In terms of innovation in healthcare, we can talk about innovation in healthcare and innovation on healthcare workers, such as nurses. Innovation and healthcare mean not only creating new technologies but also creating new work methods and new opportunities, fighting the challenges, and transforming serious crises in healthcare into successful learning progresses (Kooli 2021a). As we said before and also in the opinion of Kooli (2021a), we must also think about health professionals and the innovation related to them, since these professionals are part of the innovation that happens around them, showing the courage and sacrifice needed to care and innovate at the same time, trying to keep up with the advancement of technology, the new opportunities, and the daily struggles that are imposed on them. Likewise, and more specifically in the area of nursing, innovation covers several areas such as research, management, and training. In the health system, nurses can collaborate with the area of innovation in clinical 151 practice, contributing to improving quality in healthcare by also acting as productivity facilitators (Weng et al. 2012). Innovation in nurses involves new ideas, techniques, or procedures in healthcare to reduce costs, meet patients' needs, and improve work productivity (Weng et al. 2016).

Based on the above, the following research hypotheses were developed:

Hypothesis 6 (H6). IOE impacts innovation.

Hypothesis 7 (H7). IE impacts innovation.

\section{Conceptual Model}

According to the objective and the hypotheses based on the literature review, the following conceptual research model is proposed (Figure 1). This model was based on the articulation and incorporation of the dimensions presented having support in the scales: Cognitive Styles Index-20 items (Allinson and Hayes 1996); Individual Entrepreneurial Orientation Scale-19 items (Santos et al. 2020); Intrapreneurship Scale-9 items (Gawke et al. 2019); and Innovation Scale—22 items (Weng et al. 2012). 


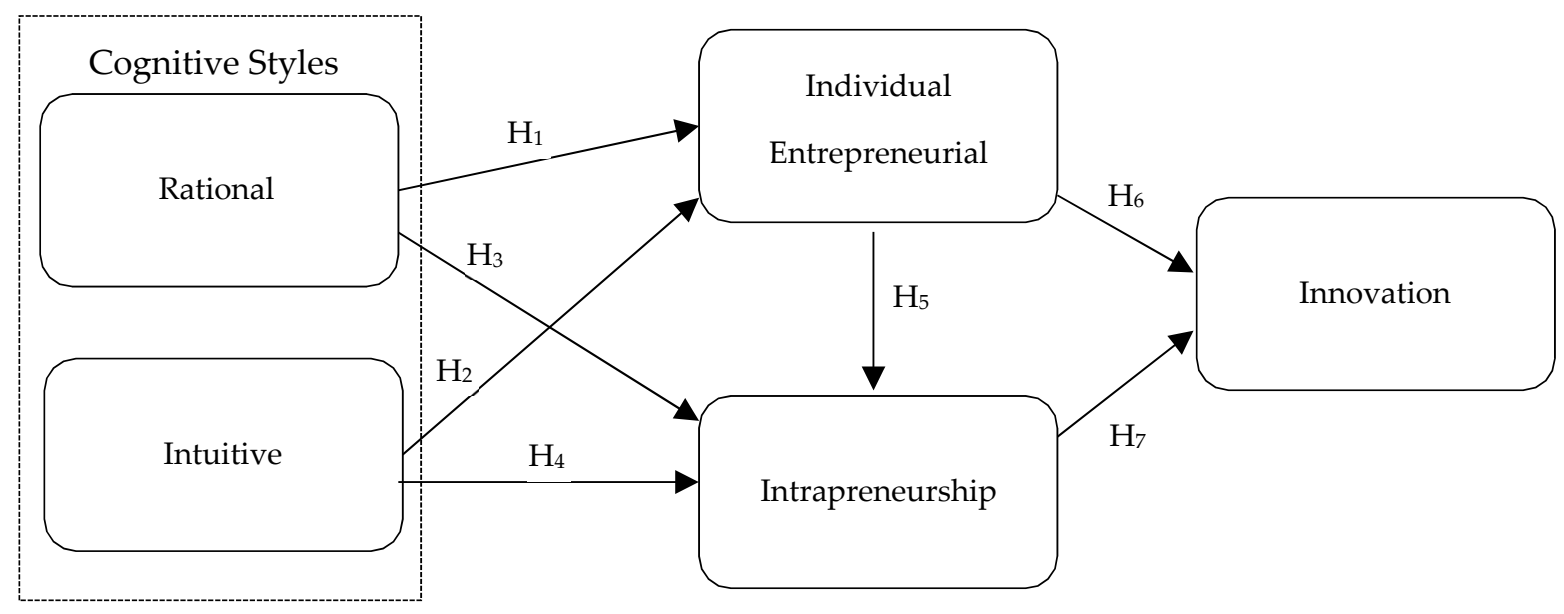

Figure 1. Conceptual research model.

\section{Methodology}

To empirically assess the proposed conceptual model, a questionnaire was developed and applied to 667 nurses working in public and private healthcare units in Portugal. The questionnaire, which was applied between 16 May 2020 and 26 September 2020, consists of 78 questions divided into 5 sections (4 corresponding to the scales used and 1 to sociodemographic questions). The scales used in the questionnaire were of the Likert type of 7 points, where the attribution " 1 " corresponds to "completely disagree" and the attribution " 7 " corresponds to "completely agree".

For data validation, the existence of missing values and outliers was checked. Once the file was validated, we proceeded to the statistical analysis and data interpretation with the support of statistical software with the focus being SmartPLS ${ }^{\circledR} 3.0$ (Ringle et al. 2015) for structural equation modelling. The univariate (frequency analysis) and multivariate (structural equation modelling) technical analyses used are described in the next section, anticipating the presentation of the results for each of the statistical analyses performed. Statistical tests were performed with a confidence level of 95\%, considering $p<0.05$ to be significant.

\section{Results}

The sample is composed of $81 \%$ women, and the most represented age group is between 36 and 45 years $(36 \%)$. Most respondents are married or cohabiting $(70.9 \%)$ and have a bachelor's degree (43\%) or a specialty / postgraduate degree (37.5\%) as academic qualifications.

Regarding the professional category, $66.1 \%$ are nurses, $31.3 \%$ are specialist nurses, and $2.5 \%$ are head nurses /managers. Of these, $84.9 \%$ perform their functions in a hospital organization. Regarding the institution, $90.4 \%$ perform functions in public institutions and $9.4 \%$ in private institutions. Almost all professionals have a permanent link with the health institution $(87.4 \%)$.

\subsection{Evaluation of the Structural Equation Model}

Since the measurement instruments corresponding to IOE and Innovation used in this study are constructs that have dimensions with their own indicators, they are second-order constructs. Thus, their psychometric properties, such as validity and reliability, were assessed in the first stage, considering the recommendations mentioned by Hair et al. (2017), calculating the scores corresponding to their dimensions which were, in the second stage, used as indicators in the final model (Becker et al. 2012).

\subsection{Evaluation of the Psychometric Properties of the Constructs "IOE" and "Innovation"}

In assessing the psychometric properties of the constructs IOE and Innovation, in the first stage, the factor loadings of its indicators were assessed, as well as the reliability 
of the internal consistency and convergent validity. Factor weights $(\lambda)$ above 0.708 are recommended because they indicate that the construct explains more than $50 \%$ of the variance of the indicator, thus providing acceptable reliability (Hair et al. 2019). Table 1 shows that all factor loadings of the Innovative Behavior indicators had values higher than 0.80 , thus verifying factor validity. After the analysis of the factor weights of the indicators and the Cross Loadings in the Innovation construct, four items from the Knowledge Creation dimension and one item from the Knowledge Diffusion dimension had to be removed, and the psychometric evaluation of the Innovation construct was performed without these indicators. All the factor loadings of the indicators of the final Innovation construct showed values higher than 0.78 , ensuring factor validity (see Table 1 ).

Table 1. Analysis of the factor weights of the "IOE" and "Innovation" constructs.

\begin{tabular}{|c|c|}
\hline Items & $\lambda$ \\
\hline \multicolumn{2}{|l|}{ IOE-Risk Propensity } \\
\hline R1-I like to venture into the unknown and take risky decisions & $0.868^{* * *}$ \\
\hline R2-I am willing to invest a large amount of time and/or money in something that can give a high return & $0.871^{* * *}$ \\
\hline R3-I tend to act boldly in risky situations & $0.925^{* * *}$ \\
\hline \multicolumn{2}{|l|}{ IOE-Innovation Capacity } \\
\hline I1-I often enjoy trying new and unusual activities & $0.875^{* * *}$ \\
\hline $\begin{array}{l}\text { I2-Generally I prefer to place strong emphasis on innovative approaches rather than previously tried and } \\
\text { tested approaches }\end{array}$ & $0.904^{* * *}$ \\
\hline I3-I prefer, when I learn something new, to try to do it my way rather than doing it like everyone else does & $0.816^{* * *}$ \\
\hline I4-I am all for trying new approaches to problem solving, rather than using methods that others generally use & $0.842^{* * *}$ \\
\hline \multicolumn{2}{|l|}{ IOE-Proactivity } \\
\hline P1-I usually act in anticipation of future problems, needs or changes & $0.873^{* * *}$ \\
\hline P2-I tend to plan ahead for projects & $0.910 * * *$ \\
\hline P3-I'd rather get up and get projects going than sit around waiting for someone else to do it & $0.896^{* * *}$ \\
\hline \multicolumn{2}{|l|}{ IOE-Passion } \\
\hline $\begin{array}{l}\text { Px1-I am passionate about spotting good opportunities, developing and creating new solutions to existing problems } \\
\text { and needs }\end{array}$ & $0.897^{* * *}$ \\
\hline $\begin{array}{l}\text { Px2-I am passionate about the process of bringing together the financial, human and social resources (e.g., contacts, } \\
\text { partnerships, among others) needed to create new projects }\end{array}$ & $0.894^{* * *}$ \\
\hline Px3-I am passionate about seeing and growing and expanding my work & $0.909^{* * *}$ \\
\hline Px4-I am passionate about what I do and when I am away from my work I can't wait to get back & $0.778^{* * *}$ \\
\hline \multicolumn{2}{|l|}{ IOE-Perseverance } \\
\hline Pe1—I reached a goal that took me some time to achieve & $0.819^{* * *}$ \\
\hline Pe2-I overcame setbacks to conquer an important challenge & $0.870 * * *$ \\
\hline Pe3-I always finish what I start & $0.778^{* * *}$ \\
\hline Pe4-Setbacks do not discourage me & $0.824^{* * *}$ \\
\hline Pe5-In many complex situations, despite seeing others give up, I persist in achieving my goals & $0.880 * * *$ \\
\hline \multicolumn{2}{|l|}{ Innovation-Knowledge creation } \\
\hline Innov_KC1—The nurse usually has many new ideas & $0.830^{* * *}$ \\
\hline Innov_KC2_-The nurse regularly researches new methods, skills and knowledge to solve problems & $0.886^{* * *}$ \\
\hline Innov_KC3_-The nurse is willing to spend time developing new ideas & $0.855^{* * *}$ \\
\hline Innov_KC5-The nurse usually proposes creative ideas in relation to patient satisfaction or hospital needs & $0.839 * * *$ \\
\hline Innov_KC8-Many new and valuable ideas have emerged from the mutual efforts of nurses and their colleagues & $0.786^{* * *}$ \\
\hline
\end{tabular}


Table 1. Cont.

\begin{tabular}{|c|c|}
\hline Items & $\lambda$ \\
\hline \multicolumn{2}{|l|}{ Innovation-Behavior for innovation } \\
\hline $\begin{array}{l}\text { Innov_BI2-The nurse enthusiastically seeks information or knowledge about new technologies, procedures } \\
\text { or techniques }\end{array}$ & $0.907^{* * *}$ \\
\hline $\begin{array}{l}\text { Innov_BI3-The nurse enthusiastically develops skills to improve existing ones in order to meet new patient or } \\
\text { hospital requirements }\end{array}$ & $0.937^{* * *}$ \\
\hline Innov_BI4-Nurses often enthusiastically seek resources to assist in the application of new ideas & $0.939 * * *$ \\
\hline Innov_BI5-The nurse frequently investigates and seeks support for new ideas & $0.914^{* * *}$ \\
\hline Innov_BI6-The nurse is able to adapt to changes in tasks or environment & $0.783 * * *$ \\
\hline Innov_BI7-The nurse enthusiastically develops appropriate plans or schedules to implement new ideas & $0.846^{* * *}$ \\
\hline \multicolumn{2}{|l|}{ Innovation-Diffusion of innovation } \\
\hline Innov_DI1-Innovation items developed by nurses are regularly discussed in the organization on formal occasions & $0.871^{* * *}$ \\
\hline Innov_DI2-Innovation items developed by nurses are regularly discussed in the organization, in private & $0.844^{* * *}$ \\
\hline Innov_DI3-Innovation items developed by nurses are usually considered valuable to the organization & $0.885^{* * *}$ \\
\hline Innov_DI4-We often use innovation items developed by the nurse & $0.911^{* * *}$ \\
\hline Innov_DI5-The innovation items developed by the nurse are adopted by other members in a short period of time & $0.865^{* * *}$ \\
\hline Innov_DI6-Many of the innovation items adopted in the organization were developed by the nurse & $0.844^{* * *}$ \\
\hline
\end{tabular}

Note: $* * * x \leq 0.001$.

The second step consisted of assessing the reliability of internal consistency using Jöreskog's (1971) composite reliability (CF), Cronbach's $\alpha$, and Dijkstra and Henseler's (2015) $\rho \mathrm{A}$. The third step addressed the convergent validity of each construct measure through the mean variance extracted (VEM) for all items in each construct. As can be seen in (Table 2), the reliability of the internal consistency was ensured for the dimensions under analysis with $\mathrm{HR}$ values all being higher than $0.70(\geq 0.895)$, as well as $\rho \mathrm{A}(\geq 0.872)$ and Cronbach's $\alpha(\geq 0.866)$ values. The VEM values proved to be above 0.697 so that they fit within the recommended range $(>0.50)$ and convergent validity was ensured (Bagozzi and Yi 1988).

Table 2. Reliability and validity of the IOE and Innovation subconstructs.

\begin{tabular}{|c|c|c|c|c|}
\hline Latent Variables and Their Dimensions & FC & $\rho_{\mathrm{A}}$ & $\alpha$ Cronbach & VEM \\
\hline \multicolumn{5}{|l|}{ Individual Entrepreneurial Orientation } \\
\hline Risk Propensity & 0.918 & 0.872 & 0.866 & 0.789 \\
\hline Capacity for Innovation & 0.919 & 0.890 & 0.882 & 0.739 \\
\hline Proactivity & 0.922 & 0.874 & 0.873 & 0.798 \\
\hline Passion & 0.926 & 0.905 & 0.893 & 0.759 \\
\hline Perseverance & 0.920 & 0.900 & 0.891 & 0.697 \\
\hline \multicolumn{5}{|l|}{ Innovation } \\
\hline Knowledge creation & 0.895 & 0.896 & 0.923 & 0.705 \\
\hline Behavior toward innovation & 0.946 & 0.949 & 0.958 & 0.791 \\
\hline Diffusion of innovation & 0.936 & 0.938 & 0.949 & 0.757 \\
\hline
\end{tabular}

To assess discriminant validity, several criteria were checked, such as Fornell-Larcker's, Cross Loadings and HeteroTrait-MonoTrait ratio (HTMT) analysis of correlations. As this last criterion is more consensual (Voorhees et al. 2016), we chose to present only this criterion. As can be seen from Tables 3 and 4, the values of the HTMT ratio of the correlations are either practically equal to the threshold value of 0.90 , in the case of "Risk Propensity" with "Innovation Capability" in IOE and "Innovation Behavior" with 
"Knowledge Creation" in Innovation, or even well below this threshold value, as is the case for the remaining dimensions, so that we consider that there is discriminant validity.

Table 3. HTMT ratio analysis of correlations in relation to IOE.

\begin{tabular}{llllll}
\hline & $\mathbf{( 1 )}$ & $\mathbf{( 2 )}$ & $\mathbf{( 3 )}$ & $\mathbf{( 4 )}$ & $\mathbf{( 5 )}$ \\
\hline (1) Risk Propensity & & & & & \\
\hline (2) Innovation Capacity & 0.901 & & & & \\
\hline (3) Proactivity & 0.676 & 0.807 & & & \\
\hline (4) Passion & 0.685 & 0.688 & 0.714 & & \\
\hline (5) Perseverance & 0.571 & 0.644 & 0.726 & 0.801 \\
\hline
\end{tabular}

Table 4. HTMT ratio analysis of correlations in relation to Innovation.

\begin{tabular}{llll}
\hline & (1) & (2) & (3) \\
\hline (1) Knowledge creation & & \\
\hline (2) Behavior toward innovation & 0.899 & \\
\hline (3) Diffusion of innovation & 0.519 & 0.594 \\
\hline
\end{tabular}

\subsubsection{Measurement Model (Outer Model)}

To check the assumptions inherent to the final measurement model, the factorial weights of the indicators of the various latent variables present in the final model were analyzed first. As can be inferred from Table 5, all the factorial weights presented values greater than 0.708 , with the exception of item CS_RS_R2_-“I perform tasks in a systematic way" of the Rational Cognitive Style, which presented a slightly lower factorial weight (0.650) and was maintained in the model.

Table 5. Analysis of the factorial weights of the final measurement model.

\begin{tabular}{|c|c|}
\hline Items & Factor Weights \\
\hline \multicolumn{2}{|l|}{ Cognitive Styles-Rational Style } \\
\hline CS_RS_R1-I ponder things carefully & $0.781^{* * *}$ \\
\hline CS_RS_R2-I perform tasks systematically & $0.650 * * *$ \\
\hline CS_RS_R3-I work things out logically & $0.794^{* * *}$ \\
\hline CS_RS_R4-I approach tasks analytically & $0.829 * * *$ \\
\hline CS_RS_R5-I focus a lot on the steps involved in accomplishing the task & $0.838 * * *$ \\
\hline CS_RS_R6-I apply precise rules to deduce answers & $0.822 * * *$ \\
\hline CS_RS_R7-I focus a lot on what I am doing to get the results & $0.859 * * *$ \\
\hline CS_RS_R8-I am aware of my thought process & $0.842 * * *$ \\
\hline CS_RS_R9-I arrived at my answers by carefully evaluating the information I had access to & $0.869 * * *$ \\
\hline CS_RS_R10-I use clear rules & $0.830 * * *$ \\
\hline \multicolumn{2}{|l|}{ Cognitive Styles-Intuitive Style } \\
\hline CS_IS_I1-I use my intuition & $0.817^{* * *}$ \\
\hline CS_IS_I2-I follow what I feel is best for me & $0.813^{* * *}$ \\
\hline CS_IS_I3-I trust my hunches & $0.885^{* * *}$ \\
\hline CS_IS_I4-I trust my intuition & $0.885^{* * *}$ \\
\hline CS_IS_I5-I trust my first impressions & $0.871^{* * *}$ \\
\hline CS_IS_I6-I use my instincts & $0.895^{* * *}$ \\
\hline CS_IS_I7-I use my heart as a guide to action & $0.824 * * *$ \\
\hline CS_IS_I8-I have flashes of insight that I use to make my decisions & $0.845^{* * *}$ \\
\hline CS_IS_I9-Ideas pop into my head & $0.810^{* * *}$ \\
\hline CS_IS_I10-I use free association, where one idea leads to the next & $0.828 * * *$ \\
\hline \multicolumn{2}{|l|}{ Individual Entrepreneurial Orientation } \\
\hline IEO_R-Risk Propensity & $0.818^{* * *}$ \\
\hline IEO_I_-Innovation Capacity & $0.868^{* * *}$ \\
\hline IEO_P-Proactivity & $0.844^{* * *}$ \\
\hline IEO_Px-Passion & $0.860 * * *$ \\
\hline IEO_Pe-Perseverance & $0.831 * * *$ \\
\hline
\end{tabular}


Table 5. Cont.

\begin{tabular}{lc}
\hline Items & Factor Weights \\
\hline Intrapreneurship & $0.865^{* * *}$ \\
\hline Intra_E1-I perform activities to make changes in my organization & $0.868^{* * *}$ \\
Intra_E2-I perform activities to change the current products/services of my organization & $0.899^{* * *}$ \\
Intra_E3-I conceptualize new ways of working for my organization & $0.863^{* * *}$ \\
Intra_E4-I use other specialists' ideas to innovate in my organization & $0.861^{* * *}$ \\
Intra_E5-I carry out activities that change the structure of my organization & $0.891^{* * *}$ \\
Intra_E6-I perform activities that change the work practices of my organization & $0.892^{* * *}$ \\
Intra_E7-I conceptualize new projects for my organization & $0.888^{* * *}$ \\
Intra_E8-I carry out activities that result in new projects within my organization & $0.728^{* * *}$ \\
Intra_E9-I actively establish collaborations with specialists outside my profession & $0.906^{* * *}$ \\
\hline Innovation & $0.810^{* * *}$ \\
\hline Innov_KC-Knowledge creation & $0.877^{* * *}$ \\
Innov_BI-Behavior for innovation &
\end{tabular}

Note: ${ }^{* *} p \leq 0.001$.

As can be seen in Table 6, the reliability of the internal consistency under analysis was ensured with HR values all being higher than $0.899(>0.70)$, and the $\rho$ A and Cronbach's $\alpha$ values were also very good. The mean variance extracted (MVE) values were above 0.662 , thus falling within the recommended interval $(>0.50)$, thus ensuring convergent validity (Bagozzi and Yi 1988).

Table 6. Reliability of the internal consistency and convergent validity of the measurement model constructs.

\begin{tabular}{lcccc}
\hline \multicolumn{1}{c}{ Latent Variables and Their Dimensions } & FC & $\boldsymbol{\rho}_{\mathbf{A}}$ & $\alpha$ Cronbach & VEM \\
\hline Cognitive Styles-Rational Style & 0.951 & 0.947 & 0.942 & 0.662 \\
\hline Cognitive Styles-Intuitive Style & 0.962 & 0.959 & 0.956 & 0.719 \\
\hline Individual Entrepreneurial Orientation & 0.925 & 0.902 & 0.899 & 0.713 \\
\hline Intrapreneurship & 0.963 & 0.958 & 0.957 & 0.745 \\
\hline Innovation & 0.899 & 0.833 & 0.832 & 0.749 \\
\hline
\end{tabular}

To assess discriminant validity, the HTMT ratio of the correlations was analyzed. As can be seen in Table 7, all values of the HTMT ratio of the correlations were lower than the threshold value of 0.90 , such that there was discriminant validity.

Table 7. HTMT ratio analysis in the final measurement model.

\begin{tabular}{|c|c|c|c|c|c|}
\hline & (1) & (2) & (3) & (4) & (5) \\
\hline \multicolumn{6}{|l|}{ (1) Cognitive Styles-Rational Style } \\
\hline (2) Cognitive Styles-Intuitive Style & 0.494 & & & & \\
\hline (3) Individual Entrepreneurial Orientation & 0.400 & 0.393 & & & \\
\hline (4) Intrapreneurship & 0.509 & 0.426 & 0.568 & & \\
\hline (5) Innovation & 0.490 & 0.447 & 0.455 & 0.521 & \\
\hline
\end{tabular}

As can be seen, the measurement model met the required criteria; therefore, we move on to the evaluation of the structural model (Hair et al. 2017).

\subsubsection{Structural Model (Inner Model)}

The evaluation of the structural model and its predictive capacity was carried out by the $R^{2}$ of the endogenous latent variables (Chin 1998) but also by the size of the $\mathrm{f}^{2}$ effects (Cohen 1988). As can be inferred from Table 8, the $\mathrm{R}^{2}$ value of "Intrapreneurship" is 
0.391, that of "Innovation" 0.254 , and that of IOE 0.189; therefore, all were higher than the acceptable cut-off point of 0.1 (Falk and Miller 1992). Effect size $\left(\mathrm{f}^{2}\right)$ complements $\mathrm{R}^{2}$ and considers the relative impact of a particular exogenous variable on an endogenous variable through changes in $R^{2}$ (Cohen 1988). Cohen (1988) suggests $\mathrm{f}^{2}$ values of $0.02,0.15$, and 0.35 for small, medium, and large effects of the predictive variables. For the model under analysis, Table 8 shows that in relation to IE, there is a medium effect on the part of the IOE with an $\mathrm{f}^{2}$ value of 0.185 , with the remaining effects of the model being small effects.

Table 8. Size of the effects of predictor variables on endogenous variables.

\begin{tabular}{lccc}
\hline \multicolumn{1}{c}{ Trajectories } & $\mathbf{R}^{2}$ & $\mathbf{f}^{2}$ & Effect of $\mathbf{f}^{2}$ \\
\hline Rational Style $\rightarrow$ IOE & 0.189 & 0.064 & Small \\
\hline Intuitive Style $\rightarrow$ IOE & 0.189 & 0.060 & Small \\
\hline Rational Style $\rightarrow$ IE & 0.391 & 0.094 & Small \\
\hline Intuitive Style $\rightarrow$ IE & 0.391 & 0.024 & Small \\
\hline IOE $\rightarrow$ IE & 0.391 & 0.185 & Medium \\
\hline IOE $\rightarrow$ Innovation & 0.254 & 0.042 & Small \\
\hline IE $\rightarrow$ Innovation & 0.254 & 0.127 & Small \\
\hline
\end{tabular}

Similarly, the predictive relevance of the model was assessed by calculating the StoneGeisser $Q^{2}$ value (Geisser 1974; Stone 1974). This procedure was carried out following the blindfolding resampling approach (considering 7 as the default distance), and in this way, the predictive power of the model was examined (Tenenhaus et al. 2005; Wold 1975). It was found that the value of $Q^{2}$ is 0.287 in the Intrapreneurship construct, 0.181 in Innovation, and 0.131 in the IOE construct and is therefore higher than zero in all constructs, thus suggesting the predictive relevance of the model (Chin 1998). Figure 2 shows the SmartPLS output of our research model with the values of the regression coefficients $(\beta)$ in the paths between the different constructs of the model, their coefficients of determination $\left(R^{2}\right)$, as well as the factorial weights of their indicators $(\lambda)$.

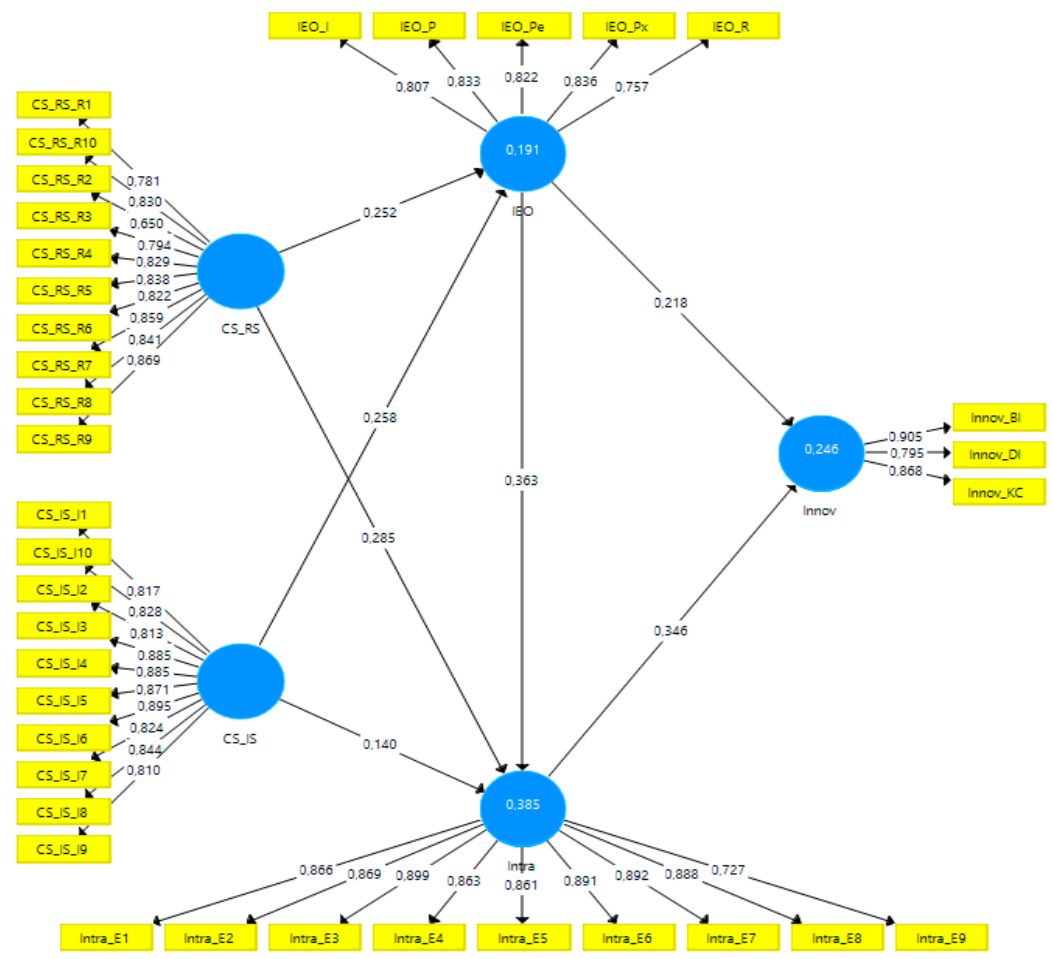

Figure 2. Output of SmartPLS. 


\section{Discussion of Results}

In view of the objective of this study, we intended to gauge how AEs promote IOE and IE and how they drive innovation in health service nurses.

Table 9 presents the results of the research hypotheses. By extracting and analyzing the data collected, we found that the seven proposed hypotheses have significance and are supported.

Table 9. Analysis of the hypotheses.

\begin{tabular}{|c|c|c|c|c|c|c|c|}
\hline Hip.: & Direct Effect & $\begin{array}{c}\text { Regression } \\
\text { Coefficient }(\beta)\end{array}$ & $p$ & $\begin{array}{l}\text { The Hypothesis } \\
\text { Is Supported? }\end{array}$ & Mediator Effect & $\begin{array}{c}\text { Regression } \\
\text { Coefficient }(\beta)\end{array}$ & $p$ \\
\hline H1: & Rational Style $\rightarrow$ IOE & 0.257 & $<0.001$ & yes & & & \\
\hline H2: & Intuitive Style $\rightarrow$ IOE & 0.249 & $<0.001$ & yes & & & \\
\hline H3: & Rational Style $\rightarrow$ IE & 0.280 & $<0.001$ & yes & $\begin{array}{c}\text { Rational Style } \rightarrow \\
\text { IOE } \rightarrow \text { IE }\end{array}$ & 0.096 & $<0.001$ \\
\hline H4: & Intuitive Style $\rightarrow$ IE & 0.141 & 0.001 & yes & $\begin{array}{c}\text { Intuitive Style } \rightarrow \\
\text { IOE } \rightarrow \text { IE }\end{array}$ & 0.093 & $<0.001$ \\
\hline H5: & $\mathrm{IOE} \rightarrow \mathrm{IE}$ & 0.373 & $<0.001$ & yes & & & \\
\hline H6: & IOE $\rightarrow$ Innovation & 0.208 & $<0.001$ & yes & $\begin{array}{l}\mathrm{IOE} \rightarrow \mathrm{IE} \rightarrow \\
\text { Innovation }\end{array}$ & 0.135 & $<0.001$ \\
\hline H7: & IE $\rightarrow$ Innovation & 0.362 & $<0.001$ & yes & & & \\
\hline
\end{tabular}

Thus, in relation to H1-“Rational CS has influence on IOE", it turned out to be positive and significant ( $\beta_{\mathrm{IOE} \cdot \mathrm{ER}}=0.257 ; p<0.001$ ) and to $\mathrm{H} 2$ - "Intuitive $C S$ has influence on IOE", equally positive and significant ( $\beta_{\text {IOE }}$ ER $=0.249 ; p=0.001$ ). We found that rational and intuitive CS positively influence IOE. However, there is a greater influence of the rational CS toward the IOE of the nurses in the sample, which is in line with the procedural and normative nursing practices, i.e., more rational and thoughtful attitudes prevail. As we can see in the analysis of the factorial weights of the final measurement model of the Rational CS dimension, there is a greater weighting in the items "I reached my answers by carefully assessing the information to which I had access", "I focus a lot on what I am doing to reach the results", and "I am aware of my thought process". In a way, we may refer that these results are expected since nurses use their rational aspect to manage their technical care. As for the analysis of the factorial weights of the final measurement model of the Intuitive CS dimension, there is a higher weighting in the items "I use my instincts", "I trust my hunches", and "I trust my intuition". It should be noted that these results may be associated with the profile of the nurses in the sample, who are in the predominant age range of 36-45 years, i.e., they are professionals above twelve years in healthcare provision and already have the clinical experience that allows for a more complex approach.

Following the study of Bendall et al. (2019), intuitive and rational individuals may have intrinsic differences in decision making, and we can infer that nurses use rational CE as an influence in the strategic thinking of IOE. In this sense, the cognitive perspective (CS) is relevant in the individual entrepreneurial process which is based on knowledge structures and mental paradigms that entrepreneurs use to make assessments, appreciations or decisions involving the evaluation of opportunities, and creation and growth of ventures (Armstrong et al. 2012).

In relation to Hypotheses $\mathrm{H} 3$ and $\mathrm{H} 4$, we found that they have a positive impact on IE. Thus, in relation to H3- "Rational CS has an influence on IE", it presents a positive and significant direct effect $\left(\beta_{\mathrm{IE}} \cdot \mathrm{ER}=0.280 ; p<0.001\right)$, also presenting a small indirect effect on IE, mediated by IOE $\left(\beta_{\mathrm{IE} \cdot \mathrm{ER} \mid \mathrm{IOE}}=0.096 ; p<0.001\right)$. H4-“"Cognitive intuitive CS influences $I E^{\prime \prime}$ is found to have a positive and significant direct relationship $\left(\beta_{\mathrm{IE} \cdot \mathrm{EI}}=0.141 ; p<0.001\right)$, presenting a small indirect effect on IE, mediated by IOE ( $\left.\beta_{\mathrm{IE} \cdot \mathrm{EI} / \mathrm{IOE}}=0.093 ; p<0.001\right)$. In this sense, and regarding research questions $\mathrm{H} 3$ and $\mathrm{H} 4$, we can conclude that rational and intuitive CS positively influence IE in healthcare units in Portugal. Thus, we corroborate the study of Allinson et al. (2010), the CS are important for the study of entrepreneurship. They also found that an intuitive approach to information processing is adopted by successful entrepreneurs. According to Pandey et al. (2020), IE increases positivity at work and helps 
employees to perform better, and there is a positive relationship between CS and IE. The studies of Marques et al. (2013) and Lages et al. (2017) state that the affective states, in this case the rational and intuitive CS, as well as the nurses' optimistic perceptions, contribute positively to the IE and intrapreneurial behaviors of healthcare teams.

H5- "IOE influences IE" proved to be positive and significant, presenting the highest regression coefficient among those presented in the proposed model ( $\beta$ IE.IOE $=0.373$; $p<0.001)$. We found that the IOE as a strategic construct impacts the IE of nurses in healthcare units in Portugal. This result is in line with the studies of Carneiro et al. (2020) and Badoiu et al. (2020), who state that the nurse entrepreneur identifies opportunities in a creative and innovative way based on trust and quality in the relationship between the employee and the manager, despite the adverse situations that arise on a daily basis, such as insufficient resources or lack of availability to carry out projects.

H6- "IOE impacts innovation" presents a positive and significant direct effect ( $\beta_{\text {Inov }} \cdot \mathrm{IOE}$ $=0.208 ; p<0.001)$, as well as a considerable indirect effect on Innovation, mediated by IE $\left(\beta_{\text {Inov }} \cdot\right.$ IOE IIE $\left.=0.135 ; p<0.001\right)$. The result of $\mathrm{H} 6$ presents a positive and significant direct effect, as well as a considerable indirect effect on Innovation, mediated by IE ( $\beta$ Inov $\cdot$ IOE IIE $=0.135 ; p<0.001$ ), corroborating the study of Wolak et al. (2019) who state that nursing teams should be involved in innovative management projects to share results. Al Issa (2020) states that for entrepreneurial success, there must be a significant relationship between IOE, interest, and perseverance of individual effort. It should also be noted that entrepreneurs creativity has a positive impact on IOE (Gao et al. 2020). For Kraus et al. (2019), employees with IOE prove to be very efficient, thus IOE is intricately linked to innovative activities.

H7 "IE impacts innovation" proved to be positive and significant ( $\beta_{\text {Inov }} \cdot \mathrm{IE}=0.362$; $p<0.001$ ). As for the research question H7, it is corroborated by the study of Manion (1990), which mentions that an intrapreneurial nurse creates innovation within the healthcare organization through the introduction of a new product, a different service, or simply a new way of doing something. In Rufaidah's (2017) study, innovation activities depend on the individuals who carry them out, either as an entrepreneur or as an employee. According to Dehghanzadeh et al. (2016), a large proportion of nurses are intrapreneurs, and this is revealed in the places where they perform roles that promote creativity and innovation. Kearney et al. (2008) found that intrapreneurs demonstrate that both risk-taking and proactivity are factors that trigger innovative activities.

\section{Conclusions}

After extracting and analyzing the collected data, we found that the seven hypotheses are supported and have significance and a positive relationship, which demonstrates the robustness of the model. We can thus state that CS positively influences nurses' IOE; there is a greater influence of the rational CS toward nurses' IOE; CS positively influences the IE, and this is mediated by the IOE; the IOE impacts nurses' IE and innovation and has an effect mediated by the IE; and the IE impacts nurses' innovation.

In summary, the CS stimulated the IOE, giving rise to the personal and organizational IE that originated innovation, mainly in the area of health and individual protection. By analyzing the IE, we found that the nurses in the sample conceptualized new projects, new ways of working, and performed activities that changed work practices in organizations.

It should be noted that, in times of the COVID-19 pandemic, the nurses in the study reported a tendency to act boldly in risky situations, persisting in achieving their goals COVID-19 changed the way of working, living, socializing, and the interactions between humans and society (Kooli 2021a); nurses began to work in adverse situations, with mirrored schedules, physical and emotional exhaustion, leading to the need for innovation and intrapreneurship within the health units, so as to provide an effective and efficient response with the quality that each patient needs. For Kooli (2021b), ethics in health is essential in medical care; it is the strength of a country to deal with emergencies and challenges related to the health system. 
The originality of this study lies in the lack of studies demonstrating the relationship between the dimensions which we proposed to analyze-innovation, IE, CS, and IOE of nurses in Portugal—as well as the fact that the sample under study was collected in the middle of the pandemic, which undoubtedly led to the results reflecting the situation to which Portuguese nurses were subjected to the pressure imposed by COVID-19.

\section{Implications and Future Suggestions}

We intend this study to contribute to the understanding of IE and innovation in nursing professionals. The combination between entrepreneurship and innovation is vital for organizational success (Urban and Wood 2017). As such, in order to promote IE in healthcare organizations, administrations should support initiative, innovation, and change (Lages et al. 2017; Wan et al. 2020). Facilitating openness in communication, CS, and trust promotes skills and attracts more employees with entrepreneurial characteristics (Lenka and Chawla 2015). Moreover, it would be advisable to investigate the influence of dominant features of cognitive styles on the intrapreneurship and innovation in healthcare units.

The main limitation felt was the scarcity of studies on the topic in the area of nursing. Demotivation, lack of professional recognition, and burnout aggravated by the pandemic may have conditioned data collection to a more comprehensive sample. We suggest the development of a comparative study between genders to understand which CS are dominant, as well as the capacity for innovation and intrapreneurship.

Author Contributions: Conceptualization, P.F., C.S.M. and G.S.; methodology, P.F., C.S.M. and G.S.; validation, C.S.M. and G.S.; investigation, P.F., C.S.M. and G.S.; resources, P.F., C.S.M. and G.S.; software, G.S.; data curation, P.F. and G.S.; writing — original draft preparation, P.F.; writing-review and editing, A.M.C. and S.V.; visualization, P.F.; supervision, C.S.M. and G.S.; funding acquisition, C.S.M. All authors have read and agreed to the published version of the manuscript.

Funding: This research was funded by national funds, through the FCT-Portuguese Foundation for Science and Technology under the project UIDB/04011/2020.

Institutional Review Board Statement: Not applicable.

Informed Consent Statement: Informed consent was obtained from all subjects involved in the study.

Data Availability Statement: Not applicable.

Conflicts of Interest: The authors declare no conflict of interest.

\section{References}

Abadli, Riad, Chokri Kooli, and Abdelhafid Otmani. 2020. Entrepreneurial culture and promotion of exporting in Algerian SMEs: Perception, reality and challenges. International Journal of Entrepreneurship and Small Business 41: 227-40. [CrossRef]

Afsar, Bilal, Yuosre Badir, and Muhammad Muddassar Khan. 2015. Person-job fit, person-organization fit and innovative work behavior: The mediating role of innovation trust. Journal of High Technology Management Research 26: 105-16. [CrossRef]

Al Issa, Hussein Elhakim. 2020. When grit leads to sucess: The role of individual entrepreneurial orientation. Business: Theory and Practice 21: 643-53. [CrossRef]

Allinson, Christopher, and John Hayes. 1996. The cognitive style index: A measure of intuition-analysis for organizational research. Journal of Management Studies 33: 119-35. [CrossRef]

Allinson, Christopher, Elizabeth Chell, and John Hayes. 2010. Intuition and entrepreneurial behavior. European Journal of Work and Organizational Psychology 9: 31-43. [CrossRef]

Antoncic, Bostjan, and Robert Hisrich. 2003. Clarifying the intrapreneurship concept. Journal of Small Business and Enterprise Development 10: 7-24. [CrossRef]

Armstrong, Steven, Eva Cools, and Eugene Sadler-Smith. 2012. Role of Cognitive Styles in Business and Management: Reviewing 40 Years of Research. International Journal of Management Reviews 14: 238-62. [CrossRef]

Awang, Amran, Shazwani Amran, Mohdniza Nor, Ima Ilyani Ibrahim, Mohd Fazly, and Mohd Razali. 2016. Individual Entrepreneurial Orientation impact on Entrepreneurial Intention: Intervening effect of PBC and Subjective Norm. Journal of Entrepreneurship, Business and Economics 4: 94-129.

Badoiu, Georgiana-Alexandra, Mercedes Segarra-Ciprés, and Ana B. Escrig-Tena. 2020. Understanding employees' intrapreneurial behavior: A case study. Personnel Review 49: 1677-94. [CrossRef]

Bagozzi, Richard, and Youja Yi. 1988. On the evaluation of structural equation models. Journal of the Academy of Marketing Science 16: 74-94. [CrossRef] 
Baron, Robert. 2004. The cognitive perspective: A valuable tool for answering entrepreneurship's basic why questions. Journal of Business Venturing 19: 221-39. [CrossRef]

Becker, Jan-Michael, Kristina Klein, and Martin Wetzels. 2012. Hierarchical latent variable models in PLS-SEM: Guidelines for using reflective-formative type models. Long Range Planning 45: 359-94. [CrossRef]

Bendall, Robert, Sarah Lambert, Adam Galpin, Lynne Marrow, and Simon Cassidy. 2019. Psychophysiological indices of cognitive style: A triangulated study incorporating neuroimaging, eye-tracking, psychometric and behavioral measures. Personality and Individual Differences 144: 68-78. [CrossRef]

Carneiro, Ana Luiza, Izamara Pereira, and Magda Rogéria Pereira Viana. 2020. Empreendedorismo: Um caminho inovador na enfermagem. Pesquisa, Sociedade e Desenvolvimento 9: e868997994. [CrossRef]

Chen, Ming-Huei, Yu-Yu Chang, and Ya-Hsun Lo. 2015. Creativity cognitive style, conflict, and career success for creative entrepreneurs. Journal of Business Research 68: 906-10. [CrossRef]

Chin, Wynne. 1998. The partial least squares approach to structural equation modeling. Modern Methods for Business Research 295: 295-336.

Cohen, Jacob. 1988. Statistical Power Analysis for the Behavioral Sciences. Hillsdale: Lawrence Erlbaum Associates.

Dehghanzadeh, Mohammad Reza, Golrasteh Kholasehzadeh, Masoumeh Birjandi, Ensieh Antikchi, Mohamad Reza Sobhan, and Hossein Neamatzadeh. 2016. Entrepreneurship psychological characteristics of nurses. Acta Medica Iranica 54: 595-99. [PubMed]

Dijkstra, Theo, and Jörg Henseler. 2015. Consistent partial least squares path modeling. MIS Quarterly 39: 297-316. [CrossRef]

Dutta, Dev, and Stewart Thornhill. 2014. Venture cognitive logics, entrepreneurial cognitive style, and growth intentions: A conceptual model and an exploratory field study. Entrepreneurship Research Journal 4: 147-66. [CrossRef]

Falk, Frank, and Nancy Miller. 1992. A Primer for Soft Modeling. Akron: University of Akron Press.

Gao, Yang, Dixuan Zhang, Hongjia Ma, and Xiaomin Du. 2020. Exploring Creative Entrepreneurs IEO: Extraversion, Neuroticism and Creativity. Frontiers in Psychology 11: 2170. [CrossRef]

Gawke, Jason, Marjan Gorgievski, and Arnold Bakker. 2018. Personal Costs and Benefits of Employee Intrapreneurship: Disentangling the Employee Intrapreneurship, Well-Being, and Job Performance Relationship. Journal of Occupational Health Psychology 23: 508-19. [CrossRef]

Gawke, Jason, Marjan Gorgievski, and Arnold Bakker. 2019. Measuring intrapreneurship at the individual level: Development and validation of the Employee Intrapreneurship Scale (EIS). European Management Journal 37: 806-17. [CrossRef]

Gawke, Jason, Marjan Gorgievski, and Arnold Bakker. 2017. Employee intrapreneurship and work engagement: A latent change score approach. Journal of Vocational Behavior 100: 88-100. [CrossRef]

Geisser, Seymour. 1974. A predictive approach to the random effect model. Biometrika 61: 101-7. [CrossRef]

Hagatong, João. 2018. A conciliação da inovação com a sustentabilidade em saúde. Revista Portuguesa de Gestão e Saúde 23: 6-11.

Hair, Joseph, Jeffrey Risher, Marko Sarstedt, and Christian Ringle. 2019. When to use and how to report the results of PLS-SEM. European Business Review 31: 2-24. [CrossRef]

Hair, Joseph, Tomas Hult, Christian Ringle, and Marko Sarstedt. 2017. A Primer on Partial Least Squares Structural Equation Modeling (PLS-SEM). Thousand Oaks: Sage.

Jöreskog, Karl. 1971. Simultaneous factor analysis in several populations. Psychometrika 36: 409-26. [CrossRef]

Kearney, Claudine, Robert Hisrich, and Frank Roche. 2008. A conceptual model of public sector corporate entrepreneurship. International Entrepreneurship and Management Journal 4: 395-13. [CrossRef]

Kickul, Jill, Lisa Gundry, Saulo Barbosa, and Laney Whitcanack. 2009. Intuition versus analysis? Testing differential models os cognitive style on entrepreneurial self-efficacy and the new venture creation process. Entrepreneurship Theory and Practice 33: 439-53. [CrossRef]

Kooli, Chokri, and Riad Abadli. 2021. Could Education Quality Audit Enhance Human Resources Management Processes of the Higher Education Institutions? Vision: The Journal of Bussiness Perspective, 1-9. [CrossRef]

Kooli, Chokri. 2019. Governing and managing higher education institutions: The quality audit contributions. Evaluation and Program Planning 77: 101713. [CrossRef]

Kooli, Chokri. 2020. Islamic Financing Initiatives Stimulating SMEs Creation in Muslim Countries. Journal of Islamic Research 31: 266-79.

Kooli, Chokri. 2021a. COVID-19: Challenges and opportunities. Avicenna Editorial 1: 5. [CrossRef]

Kooli, Chokri. 2021b. COVID-19: Public health issues and Ethical Dilemmas. Ethics, Medicine and Public Health 17: 100635. [CrossRef]

Kraus, Sascha, Matthias Breier, Paul Jones, and Mathew Hughes. 2019. Individual entrepreneurial orientation and intrapreneurship in the public sector. International Entrepreneurship and Management Journal 15: 1247-68. [CrossRef]

Lages, Marisa Filipa, Carla Susana Marques, João José Matos Ferreira, and Fernando Alberto Ferreira. 2017. Intrapreneurship and firm entrepreneurial orientation: Insights from the health care service industry. International Entrepreneurship and Management Journal 13: 837-54. [CrossRef]

Lenka, Usha, and Saniya Chawla. 2015. Higher educational institutes as learning organizations for employer branding. Industrial and Commercial Training 47: 265-76. [CrossRef]

Lumpkin, G. T., Claudia Cogliser, and Dawn Schneider. 2009. Understanding and measuring autonomy: An entrepreneurial orientation perspective. Entrepreneurship Theory and Practice 33: 47-69. [CrossRef]

Manion, Jo. 1990. Change from Within: Nurse Intrapreneurs as Health Care Innovators. American Nurses Association Publications G-178 i-xii: $1-171$. 
Marques, Carla Susana, Cândido Lopes, Vitor Braga, Vanessa Ratten, and Gina Santos. 2021. Intuition and rationality in intrapreneurship and innovation outputs: The case of health professionals in primary health care. International Entrepreneurship and Management Journal 17: 1-24. [CrossRef]

Marques, Carla Susana, João José Matos Ferreira, Fernando Alberto Ferreira, and Marisa Filipa Lages. 2013. Entrepreneurialorientation and motivation to start up a business: Evidence from the health service industry. International Entrepreneurship and Management Journal 9: 77-94. [CrossRef]

Marques, Carla Susana, Sandra Valente, and Marisa Filipa Lages. 2018. The influence of personal and organisational factors on entrepreneurship intention: An application in the health care sector. The Journal of Nursing Management 26: 696-706. [CrossRef] [PubMed]

Messabia, Nabil, Ngo Ngue Marguerite, and Chokri Kooli. 2020. Technological Change in Banking as Perceived by Employees: The experience of a Canadian Branch. Journal of Financial, Accounting and Managerial Studies 7: 639-61.

Neessen, Petra, Marjolein Caniëls, Bart Vos, and Jeroen de Jong. 2019. The intrapreneurial employee: Toward an integrated model of intrapreneurship and research agenda. International Entrepreneurship and Management Journal 15: 545-71. [CrossRef]

Ortiz-Hunt, Angelique, Richard Hunt, and Daniel Lerner. 2019. Sustainable Human Healthcare: The Centrality of Intrapreneurial Nurses. Academy of Management 2019: 12403. [CrossRef]

Pandey, Jatin, Manish Gupta, and Yusuf Hassan. 2020. Intrapreneurship to engage employees: Role of psychological capital. Manage Decision 59: 1525-45. [CrossRef]

Ringle, Christian, Sven Wende, and Jan-Michael Becker. 2015. SmartPLS 3. SmartPLS Software.

Rufaidah, Popy. 2017. Branding strategy development based on innovative behaviour. International Journal of Business and Globalisation 18: 396-416. [CrossRef]

Santos, Gina, Carla Susana Marques, and João José Matos Ferreira. 2020. Passion and perseverance as two dimensions of an Individual Entrepreneurial Orientation scale. Journal of Business Research 112: 190-99. [CrossRef]

Stone, Mervyn. 1974. Cross-validatory choice and assessment of statistical predictions. Journal of the Royal Statistical Society: Series B (Methodological) 36: 111-33.

Tabak, Akif, Ahmet Erkus, and Cem Meydan. 2010. The relationship between locus of control and innovative individual behaviors: Mediating effect of tolerance for ambiguity and risk taking on innovativeness. Anadolu University Journal of Social Sciences 10: 159-76.

Tenenhaus, Michel, Vincenzo Esposito Vinzi, Yves-Marie Chatelin, and Carlo Lauro. 2005. PLS path modeling. Computational Statistics and Data Analysis 48: 159-205. [CrossRef]

Urban, Boris, and Eric Wood. 2017. The innovating firm as corporate entrepreneurship. European Journal of Innovation Management 20: 534-56. [CrossRef]

Voorhees, Clay, Michael Brady, Roger Calantone, and Edward Ramirez. 2016. Discriminant validity testing in marketing: An analysis, causes for concern, and proposed remedies. Journal of the Academy of Marketing Science 44: 119-34. [CrossRef]

Wan, Wenhai, Longjun Lui, and Xinxin Wang. 2020. How user-driven innovation and employee intrapreneurs hip promote platform enterprise performance. Management Decision 58: 2705-23. [CrossRef]

Weng, Rhay-Hung, Ching-Yuan Huang, Jin-An Huang, and Man-His Wang. 2012. The cross-level impact of patient safety climate on nursing innovation: A cross-sectional questionnaire survey. Journal of Clinical Nursing 21: 2262-74. [CrossRef]

Weng, Rhay-Hung, Ching-Yuan Huang, Li-Mei Chen, and Li-Yu Chang. 2013. Exploring the impact of transformational leadership on nurse innovation behaviour: A cross-sectional study. Journal of Nursing Management 23: 427-39. [CrossRef] [PubMed]

Weng, Rhay-Hung, Wan-Ping Chen, Ching-Yuan Huang, Chiu-Hsia Hung, and Ching-Tai Hsu. 2016. Can nurse innovation improve customer perception of service quality and experience? Journal of Clinical Nursing 25: 1950-61. [CrossRef] [PubMed]

Wolak, Erica, Angela Overman, Beth Wills, Christine Hedges, and Glen Spivak. 2019. Maximizing the Benefit of Quality Improvement Activities. Journal of Nursing Care Quality 35: 199-205. [CrossRef] [PubMed]

Wold, Herman. 1975. Path models with latent variables: The NIPALS approach. In Quantitative Sociology: International Perspectives on Mathematical and Statistical Modeling. Edited by Blalock Hubert, A. Aganbegian, F. Borodkin, Raymond Boudon and Vittorio Capecchi. New York: Academic Press, pp. 307-57. 